\title{
VARIATIONS ON A THEORY OF NORMATIVE FEDERALISM: A SUPREME COURT DIALOGUE
}

\author{
ANN ALTHOUSE $\uparrow$ \\ INTRODUCTION
}

"This is a case about federalism." So wrote Justice Sandra Day O'Connor in 1991 in Coleman v. Thompson. ${ }^{1}$ It was a case about rape and murder; a case about a guilty verdict and a death penalty; a case about numerous alleged violations of constitutional rights; a case about an attorney who filed a notice of appeal three days late; a case about the merciless forfeiture that follows from procedural default-the chilling reality of three days' delay leading directly to death, without a pause to reflect on the constitutional soundness of the trial. But as Justice O'Connor saw it, it was "a case about federalism."

Justice Harry A. Blackmun responded:

Federalism ... has no inherent normative value: it does not, as the majority appears to assume, blindly protect the interests of States from any incursion by the federal courts. Rather, federalism secures to citizens the liberties that derive from the diffusion of sovereign power. "Federalism is a device for realizing the concepts of decency and fairness which are among the fundamental principles of liberty and justice lying at the base of all our civil and political institutions."

$\dagger$ Associate Professor, University of Wisconsin Law School. I would like to thank the editors of the Duke Law Joumal for inviting me to present the 1992-1993 Duke Law Journal Lecture. This Article is based on that speech. I would also like to thank the Smongeski Fund, the University of Wisconsin Foundation, and the Vilas Fund for their generous support.

1. 111 S. Ct. 2546,2552 (1991).

2. Id. at 2569-70 (Blackmun, J., dissenting) (quoting William J. Brennan, Jr., Federal Habeas Corpus and State Prisoners: An Exercise in Federalism, 7 UTAH L. REV. 423, 442 (1961)); see also THE FEDERALIST No. 51, at 324 (James Madison) (Clinton Rossiter ed., 1961) ("Justice is the end of government. It is the end of civil society."). 
Does Justice O'Connor really espouse a version of federalism bereft of meaningful purpose, a mere blind protection of state interests? This past Term, writing again for the majority on the subject of federalism, Justice O'Connor denied the accusation: "State sovereignty is not just and end in itself . ..."3 She even repeated Justice Blackmun's language: "[F]ederalism secures to citizens the liberties that derive from the diffusion of sovereign power." 4

So, a point of convergence appears. In the midst of an ongoing dialogue about the respective powers of the state and national governments, voices on both sides agree that the Constitution preserves federalism, not simply to pay respect to the states, but to protect the people. States do not retain power for their own sake, but for the sake of their citizens. Federalism is no mere vestige of the pre-constitutional era, a grudging concession saddling us today because of the unfortunate historical fact that the states existed at the time of the framing of the Constitution. The states are a means; the end is the liberty of their citizens. States are valuable alternative governments which have power because it benefits the people to diffuse power.

Let us mark this satisfying moment of harmony in the dialogue about federalism by naming it. I am going to call it the theory of "normative federalism." All members of the Court appear to agree that federalism exists for a purpose; none subscribes to "blind deference" or "empty federalism" or "States' rights." Nor does any Justice reject federalism altogether or view the states as disposable obstacles to the preferred goal of national supremacy. Thus, normative federalism is a point of convergence. But a point of convergence is only a point from which to diverge again, and, as anyone familiar with the Court will expect, the purposes different Justices ascribe to federalism do vary.

Some years ago, in Younger v. Harris, ${ }^{5}$ perhaps the central landmark of modern federalism, Justice Hugo Black advocated ing)).

3. New York v. United States, 112 S. Ct. 2408, 2431 (1992).

4. Id. (quoting Coleman v. Thompson, $111 \mathrm{~S}$. Ct. at 2570 (Blackmun, J., dissent-

5. 401 U.S. 37 (1971) (requiring federal courts to refrain from enjoining an ongoing criminal proceeding in a state court capable of enforcing the federal rights asserted in the federal case). 
a proper respect for state functions, a recognition of the fact that the entire country is made up of a Union of separate state governments, and a continuance of the belief that the National Government will fare best if the States and their institutions are left free to perform their separate functions in their separate ways. . . . The concept does not mean blind deference to "States' Rights" any more than it means centralization of control over every important issue in our National Government and its courts. The Framers rejected both these courses. What the concept does represent is a system in which there is sensitivity to the legitimate interests of both State and National Governments, and in which the National Government, anxious though it may be to vindicate and protect federal rights and federal interests, always endeavors to do so in ways that will not unduly interfere with the legitimate activities of the States. ${ }^{6}$

Rejecting "States' rights" and "blind deference" and stressing the benefits of "separate function[ing]," Justice Black's words exemplify normative federalism. The term he coined and capitalized was "Our Federalism," which suggests a shared understanding of the normative purpose the states were and are intended to serve. Yet only a general point of convergence exists; the "Our" in "Our Federalism" disguises a diversity of meaning which this Article explores. Descending from the high level of generality at which the word "Our" makes sense, this Article examines the details of the types of federalism embraced by Justice Blackmun and Justice O'Connor. As we shall see, "Blackmun's Federalism" and "O'Connor's Federalism" rest on very different ideas about the sort of benefits to be gained from diffusion of power between the national government and the states. ${ }^{8}$

This Article analyzes the Court's recent dialogue about federalism, revealing the convergence and ultimate divergence over its

\section{Id. at 44 .}

7. Id.

8. Given the divisions on the Court and the Justices' penchant for writing separate opinions, individual Justices make fruitful objects of study. See, e.g., M. David Gelfand \& Keith Werhan, Federalism and Separation of Powers on a "Conservative" Court: Currents and Cross-Currents from Justices O'Connor and Scalia, 64 TUL. L. REv. 1443 (1990); Suzanna Sherry, Civic Virtue and the Feminine Voice in Constitutional Adjudication, 72 VA. L. Rev. 543 (1986) (analyzing the work of Justice O'Connor); Richard A. Cordray \& James T. Vradelis, Comment, The Emerging Jurisprudence of Justice O'Connor, $52 \mathrm{U}$. CHI. L. REV. 389 (1985). 
meaning. Part I looks in particular at the habeas case Coleman $v$. Thompson, ${ }^{9}$ in which Justice Blackmun makes his strongest statement of the need for normativity in habeas and stresses the constitutional rights of the isolated individual. Part II then examines two recent Tenth Amendment, substantive federalism cases, Gregory $v$. Ashcroft ${ }^{10}$ and New York v. United States, ${ }^{11}$ in which Justice O'Connor elaborates a normative federalism of her own. Although she agrees with Justice Blackmun that federalism ought to benefit the people, instead of the isolated rights-claimants Justice O'Connor sees the larger community-the electorate-as federalism's proper beneficiary, and she spins out a theory of federalism premised on democracy. Throughout, the Article considers these two theories as they edge close to each other but refuse to harmonize. Fimally, the Article critiques both positions and envisions a salutory future dialogue about normative federalism.

I. JUSTICE BLACKMUN's THEORY OF NORMATIVE FEDERALISM: THE INDIVIDUAL CITIZEN as Isolated RIGHTS ClaimanT

A. Coleman v. Thompson and the Procedural Default in State Court

A Virginia state trial court convicted Roger Keith Coleman of rape and murder and sentenced him to die. The Virginia Supreme Court affirmed this conviction and the U.S. Supreme Court denied certiorari. ${ }^{12}$ Coleman then sought habeas relief, and because he was raising constitutional claims that he had not yet presented to the state court, he filed his petition in state court. ${ }^{13}$ The state court held a two-day evidentiary hearing, but denied relief. ${ }^{14}$ Coleman then filed a notice of appeal-three days late-violating the state supreme court's thirty-day limit. ${ }^{15}$

The effect the state of Virginia gave to this violation of a procedural rule would become crucial when Coleman shifted to federal district court for habeas relief. Although at one time fed-

9. 111 S. Ct. 2546 (1991).

10. 111 S. Ct. 2395 (1991).

11. 112 S. Ct. 2408 (1992).

12. Coleman v. Commonwealth, 307 S.E.2d 864 (Va. 1983), cert. denied, 465 U.S. 1109 (1984).

13. Coleman, 111 S. Ct. at 2552-53.

14. Id.

15. Id. (citing VA. SuP. Cr. R. 5:9(a)). 
eral habeas courts could ignore all but deliberate violations of state court procedural rules, ${ }^{16}$ the Supreme Court revised habeas corpus doctrine in Wainwright v. Sykes ${ }^{17}$ so that federal courts would almost always defer to the state's law of procedural default. Thus, in Sykes itself, because state law barred a constitutional challenge to the admission of evidence not raised contemporaneously, the federal habeas court could not consider the constitutional claim either, even though this result meant that no court would hear the claim of federal right. ${ }^{18}$ After Sykes, only a showing of "cause and prejudice"19 or "probable actual innocence"20 would permit the federal habeas petitioner to escape the operation of state default law. ${ }^{21}$

16. See Fay v. Noia, 372 U.S. 391 (1963), abrogated by Coleman v. Thompson, 111 S. Ct. 2546 (1991).

17. 433 U.S. 72 (1977).

18. Id. at 87. In Sykes, the Court emphasized the "state interest" in orderly procedure represented by the contemporaneous objection rule. This respect for procedure contrasts with the view taken by the Warren Court. Not only did the Warren Court announce Noia, 372 U.S. at 391, which dealt with the treatment of procedural default at the federal habeas stage, but in Henry v. Mississippi, 379 U.S. 443 (1965), a case that extended Noia to direct appeals to the U.S. Supreme Court, it wrote about the contemporaneous objection rule as if it were of little significance to the state and represented interests that might be equally well accomodated within a motion for a directed verdict. The state interest in having its own rules followed-its own choice of how to further its interests-had no weight against the federal interest in enforcing federal rights. Similarly, the Noia Court, minimizing the significance of failure to appeal from the state court conviction, wrote: "Whatever residuum of state interest there may be under such circumstances is manifestly insufficient in the face of the federal policy ... of affording an effective remedy for restraints contrary to the Constitution." 372 U.S. at 433-34.

19. Sykes, 433 U.S. at 90-91. Sykes left the "cause and prejudice" standard to develop over the years. The standard as described in later cases is notoriously difficult to meet. Basically, some force outside of the control of the accused, such as prosecutorial misconduct, must have caused the default. Mere mistake, undoubtedly the most common explanation for default, is not enough, unless the defendant's lawyer fell to such a low level as to violate the Sixth Amendment right to counsel. See Murray v. Carrier, 477 U.S. 478, 486-88 (1986) (O'Connor, J.).

20. Carrier, 477 U.S. at 496; Sawyer v. Whitley, 112 S. Ct. 2514 (1992). Some members of the Court, deemphasizing innocence, cite Carrier as providing an escape from default where there has been a "miscarriage of justice." See, e.g., Harris v. Reed, 489 U.S. 255, 258 (1989) (Blackmun, J.). The debate over whether habeas corpus exists only or primarily to provide rehef to the innocent, as opposed to the rights-bearer, is longrunning and hard-fought. For recent treatments of the subject, see Teague v. Lane, 489 U.S. 288 (1989) (creating an innocence-related exception to the rule barring the assertion of a "new rule" on habeas), and Herrera v. Collins, 113 S. Ct. 853 (1993) (discussing "actual innocence" outside of the context of procedural default). The classic statement of the innocence position is Henry J. Friendly, Is Innocence Irrelevant? Collateral Attack on Criminal Judgments, 38 U. CHI. L. REV. 142 (1970).

21. Until Coleman, the Court had never explicitly overruled Noia, which dealt with 
Undoubtedly Coleman had violated a state procedural rule, but did Virginia regard that violation as a default, barring consideration on appeal? One might think that the state supreme court's rule barring untimely appeals would determine the answer definitively, leaving the federal habeas court to consider only whether Coleman could avoid the default rule by showing "cause and prejudice" or "probable actual innocence." But the state supreme court, as the ultimate authority on the meaning of the state's law of default, might devise exceptions, which would become the state law to which federal courts would defer. If the state supreme court decided Coleman's constitutional claims despite his procedural lapse, the federal courts could do so as well..$^{22}$

The state, as Coleman's adversary on appeal, had moved to dismiss the appeal on the ground of untimeliness, but the state supreme court's order granting that motion did not make it explicit that procedural default-and procedural default alone-motivated the dismissal..$^{23}$ To put it in the jargon of federal courts law, the state supreme court did not make a clear statement that its decision rested on an independent state ground. ${ }^{24}$ It is possible that the court had looked past the procedural default and decided that the constitutional claims lacked merit, and in so doing had exercised its power to make exceptions and qualifications to its own rules. Moreover, the parties had argued the merits of the constitutional claims in their state appellate court briefs and the

the decision whether to appeal, but instead had merely extended Sykes, which dealt with the failure to make a conteinporaneous objection to evidence offered at trial. See, e.g., Carrier, 477 U.S. at 496 (applying Sykes to the failure to raise a particular claim on appeal). Until Coleman, arguments could still be made that the failure to appeal at all should be treated with the inore forgiving "deliberate bypass" test announced in Noia.

22. Coleman, $111 \mathrm{~S}$. Ct. at 2554-55. In doing so, federal courts would simply be following the state's law concerning the effect of the default and thus would defer to the state. The federal interest in the uniformity of federal law would also support this course of action. If the state court did go on to interpret federal constitutional law, then the federal court ought to examine that interpretation. It should be noted that this view of the federal interest in federal law is controversial. On the one hand, one could say that the important thing is to have one court of sufficient skill interpret the federal law. If the state court does not consider the constitutional claim because of the procedural default, arguably the federal habeas court ought to hear the claim so that one court will have addressed the asserted rights. On the other hand, if the state court does address the constitutional claim, one could say (unless the state court was inadequate) that the rights claimant has had one shot at a court, and that is sufficient. Under the current law of procedural default, the rights claimant receives either two shots or none.

23. Id. at 2556.

24. Id. at 2555 . 
state court had taken more than five months to issue its order. ${ }^{25}$ All of this suggests that the state court may have silently decided the federal questions lacked merit. If it did, it is clear that the federal courts have an important role to play in vindicating the supremacy of federal law.

\section{B. Intimations of Justice O'Connor's Theory of Normative Feder- alism in Michigan v. Long}

1. Establishing the Presumption in Favor of Supreme Court Jurisdiction. The key case governing the independent state ground doctrine, Michigan v. Long, ${ }^{26}$ was one of Justice O'Connor's earliest opinions. Long dealt not with habeas but with a direct appeal to the U.S. Supreme Court. The state court had overturned the defendant's conviction, resting its decision on the individual's right to be free from unreasonable searches and citing both the state and federal constitutional provisions. ${ }^{27} \mathrm{~A}$ state constitutional right can provide more protection to the accused than federal law does-but it need not. A state court that believes the accused has a right under federal law may cite the state constitution as an alternative source of law only because it views the state law as a mirror image of the federal law. ${ }^{28}$ If so, the state ground is not independent from the federal ground: A different interpretation of the federal law would produce a change in the state law. ${ }^{29}$ Prior to Long, the Supreme Court had used an assortment of different methods to resolve the ambiguity surrounding the issue of the independence of the state's constitutional law. ${ }^{30}$ Sometimes it

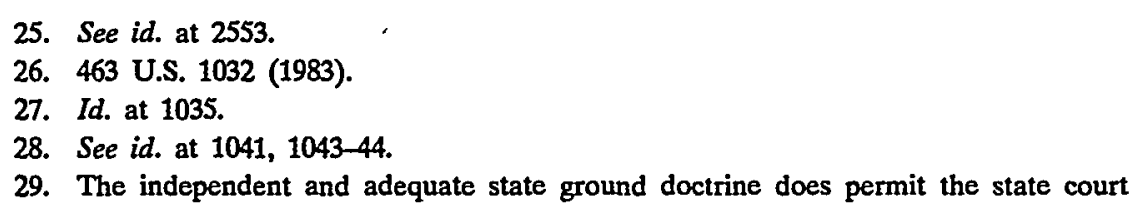
to decide federal law as an alternative holding. So the interest in protecting the supreinacy of federal law was never fully protected even under Long. The state might say something absurdly wrong about federal law, and as long as it inade a clear statement that its state law basis stood independent, the federal court cannot review it. For a "case," to exist within the meaning of Article III of the Constitution, a federal court unust have a potential impact on the outcome affecting the parties. In the frequently quoted language of Herb v. Pitcairn, 324 U.S. 117, 126 (1945), "We are not permitted to render an advisory opinion, and if the same judgment would be rendered by the state court after we corrected its views of federal laws, our review could amount to nothing more than an advisory opinion."

30. Long, 463 U.S. at 1038. 
would try to extract a clarification from the state court ${ }^{31}$ and endure the consequent delay. Other times, delving into the state precedents and risking an incorrect interpretation, the Court would try to discern the state court's theory of state constitutional law. ${ }^{32}$ Ostensibly seeking a simple resolution to the repeating problem, Justice O'Connor fashioned a presumption in favor of federal jurisdiction:

[W] hen, as in this case, a state court decision fairly appears to rest primarily on federal law, or to be interwoven with the federal law, and when the adequacy and independence of any possible state law ground is not clear from the face of the opinion, we will accept as the most reasonable explanation that the state court decided the case the way it did because it believed that federal law required it to do so. ${ }^{33}$

The state court could then rebut the presumption by stating "clearly and expressly" that it based its decision on "bona fide separate, adequate, and independent grounds." 34

2. Variations on Normative Federalism in Long. One might have thought that a Justice who valued federalism would, upon deciding to solve the problem with a presumption, presume against jurisdiction and thereby leave the state alone. ${ }^{35}$ In Long Justice Stevens, dissenting, suggested that approach. Both Justice O'Connor and Justice Stevens spoke of federal interests, but they elaborated these interests very differently. Justice O'Connor emphasized the "important need for uniformity in federal law."36 Justice Stevens, however, wanted only to weigh the federal interest in protecting the rights of individuals. ${ }^{37}$ Since only the state

31. Id. at 1038-39 (citing Herb, 324 U.S. at 117).

32. Id. at 1039 (citing Texas v. Brown, 460 U.S. 730 (1983)).

33. Id. at 1040-41.

34. Id. at 1041.

35. Justice O'Connor did purport to show respect to the states through the use of her presumption on the theory that the earlier practice of resolving anbiguity by interpreting state law impinged on the states' lawmaking functions. See id. at 1039-40.

36. Id. at 1040 .

37. As Justice Stevens put it:

In this case the State of Michigan has arrested one of its citizens and the Michigan Supreme Court has decided to turn him loose. The respondent is a United States citizen as well as a Michigan citizen, but since there is no claim that he has been mistreated by the State of Michigan, the final outcome of the state processes offended no federal interest whatever. 
would appeal from a decision that seemingly granted rights under both state and federal law, to presume against Supreme Court jurisdiction would give autonomy to a state that had at worst mistakenly given someone too many rights. Justice Stevens thus asserted a version of normative federalism: $\mathrm{He}$ would tie deference to the purpose of furthering individual rights. The federal judiciary should not intrude on the state when to do so has no potential to increase the protection of rights.

Justice O'Connor may, at first glance, seem to have forgotten about federalism altogether and either exaggerated the importance of correctness and uniformity in federal law or covertly decided to facilitate a Supreme Court agenda to narrow or curb the expansion of constitutional rights. This view of Long will fuel suspicion that "federalism" is merely a lofty-sounding word, used to mask hostility to rights, that drops out of the judicial vocabulary when a state fails to share that hostility ${ }^{38}$ It would amount to normative federalism only if one could characterize the minimization of the rights of the accused as ultimately a benefit to the citizenry as a whole, a view the Court would scarcely espouse openly.

On second glance, however, Long may seem to offer a neutral and reasonable balance of state and federal interests. The Supreme Court can determine its jurisdiction expeditiously and eradicate misimpressions about the meaning of federal law, and the state court can claim autonomy by expressing itself clearly. ${ }^{39}$ This is a purposive federalism that ties deference to the effective functioning of the state courts. It may seem to encourage state courts to perform at a higher level, more worthy of deference, by writing clear and straightforward opinions. Yet, normative federalism has, at

Id. at 1068 (Stevens, J., dissenting).

38. See, e.g., Gene R. Nichol, Jr., Book Review, An Activism of Ambivalence, 98 HARV. L. REV. 315, 321 n.39 (1984).

39. See, e.g., Thomas E. Baker, The Ambiguous Independent and Adequate State Ground in Criminal Cases: Federalism Along a Möbius Strip, 19 GA. L. REv. 799, 822 (1985); Martin H. Redish, Supreme Court Review of State Court "Federal" Decisions: A Study in Interactive Federalism, 19 GA. L. REV. 861, $864-65$ (1985); David A. Schlueter, Federalism and Supreme Court Review of Expansive State Court Decisions: A Response to Unfortunate Impressions, 11 HASTINGS L.Q. 523, 525 (1984); Richard A. Seid, Schizoid Federalism, Supreme Court Power and Inadequate Adequate State Ground Theory: Michigan v. Long, 18 CREIGHTON L. REV. 1, 64 (1984); Robert C. Welsh, Reconsidering the Constitutional Relationship Between State and Federal Courts: A Critique of Michigan v. Long, 59 NOTRE DAME L. REV. 1118, 1129-31 (1984). 
least as a general point of convergence for the Court, ${ }^{40}$ a purpose of benefitting individual citizens through the diffusion of power. Rewarding clear writing and punishing ambiguity has little if any connection to this purpose.

But a genuinely close and realistic look at Michigan $v$. Long $^{41}$ suggests a theory of normative federalism that Justice O'Connor explicates in her more recent opinions, Gregory $v$. Ashcroff ${ }^{42}$ and New York v. United States, ${ }^{43}$ discussed in Part II of this Article. Federalism diffuses power, according to these recent cases, to enhance democratic self-governance. The persons who benefit from this normative federalism are not the individual rights-claimants like Roger Keith Coleman and David Long, but the citizens of the states, who form preferences that they express through the democratic process.

3. Long and the Benefits of Democratic Self-Governance. To see the connection between democracy and cases in which individual rights-claimants litigate against the state, one must first understand the most important criticism of Long. This criticism is essentially a response to the "second glance" position described above that characterizes Long as a fair balance of interests, empowering the state courts to declare their autonomy through the simple and straightforward device of making clear statements. One may argue that clear statements are not so easy for state judges, who, unlike federal judges, face reelection. A clear statement of reliance on state law entails far more than plain English. It demands political courage.

State judges who want to expand the rights of an unpopular group, such as the criminally accused, may not want to call attention to their independence and thereby make themselves targets for political retaliation. ${ }^{44}$ By obscuring the source of the expand-

\footnotetext{
40. See supra Introduction.

41. 463 U.S. 1032 (1983).

42. 111 S. Ct. 2395 (1991).

43. 112 S. Ct. 2408 (1992).

44. Insulation from popular pressures has long been regarded as the distinctive strength of the federal judge. Immunized against voter wrath with their constitutional guarantee of life tenure, federal judges can uphold enduring principles and work as a countervailing force against the excesses of democracy. Those who einphasize federal court access and lack faith in the quality of state courts point to the democracy difference: Without life tenure, most state judges have an incentive to protect their livelihoods by appeahing to the majority. See, e.g., Burt Neuborne, The Myth of Parity, 90 HARV. L.
} 
ed rights they announce, state judges may create the impression that they act under the coercion of federal law and thus deflect voter wrath. If Long had adopted Justice Stevens's version of the presumption, state judges could not only avoid voter scrutiny, but could also avoid Supreme Court review. Justice O'Connor's presumption forces state judges to endure one form of scrutiny or the other and deprives them of the ability to immunize themselves with ambiguity. Critics of Long's balance of interests who tend to share Justice Stevens's version of normative federalism may regret this loss of immunity, because it enabled state judges-courageous and career-sacrificing or not-to expand individual rights.

If one sees the citizenry at large as the beneficiaries of federalism, however, Justice O'Connor's presumption makes sense. For people to form and express preferences in the democratic process, they need to learn what actions their government takes and who bears responsibility. Empowering their representatives to blur the lines of responsibility does not benefit the electorate. Rather, it introduces dysfunction into the democratic process. It is true, of course, that federal constitutional rights should endure in the face of popular opposition, but the state judge may still, after Long, rely on federal law-at the risk of review by the U.S. Supreme Court, which, as the final authority on those rights, may give those rights a narrower scope. But if the state judge chooses the state constitution as the source of the expansive rights he announces, the judge must, within a democratic theory of normative federalism, reveal that information to the citizens of the state. They may respond to this information by electing judges who take a more constrained approach to the interpretation of rights or by pressing for amendment of their state constitution. These are prerogatives of democracy at the state level, which Justice O'Connor and the Justices who vote with her view as appropriate norms.

REV. 1105, 1116 (1977). The difference in political sensitivity is probably overstated. Federal judges are selected, nominated, and affirmed by political officeholders. And state judges usually base their election campaigns on general competence and character, not on specific political issues. Though at some point a controversial political issue may make enough of an impression on voters to lead to political defeat, most voters do not follow the courts closely enough to retaliate at election time. Some state judges do receive lifetime jobs, or at least very long terms. Finally, even judges who do not worry about elections have political beliefs, are aware of public sentiment, and do not entirely eliminate this background from their legal decisionmaking, whether they try to or not. 
4. Expanding the Long Presumption to Procedural Defaults and to Habeas Corpus. Although some have contended that Long revealed the Supreme Court's hostility to rights, ${ }^{45}$ later developments extending the Long presumption to procedural defaults and to habeas corpus undercut that position. Long involved the confusion of state substantive rights with federal rights: Only the prosecution stood to gain from the presumption, which allowed the Supreme Court to examine whether the state court had overprotected a criminal defendant. (If the convicted defendant had lost an appeal that asserted federal rights, the Supreme Court would, because of the supremacy of federal law, have the power to review the federal law regardless of whether a state constitutional right had also been interpreted narrowly.) But a state procedural law ground could result in a loss for the accused and bar review of the federal substantive right. When it decided to apply the Long presumption to issues of procedural default on habeas in Harris $v$. Reed ${ }^{46}$ the Court increased the likelihood of expanding the protection given to individual rights-claimants.

Justice Blackmun, whose normative federalism, like Justice Stevens's, aims at rights enforcement, wrote the majority opinion in Harris. He was, as one might expect, joined by Justices Brennan, White, Marshall, and Stevens. ${ }^{47}$ But Justice O'Connor, not associated with this position, also signed Justice Blackmun's opinion. ${ }^{48}$

45. See supra text accompanying note 38 .

46. 489 U.S. 255 (1989).

47. Chief Justice Rehnquist and Justice Scalia also joined Justice Blackmun's opinion. Justice Kennedy alone dissented.

48. Justice O'Connor also wrote "separately to emphasize two points." First, she clarified the effect on the exhaustion requirement, 28 U.S.C. \$ 2254(c) (1988) (forbidding federal habeas access if the petitioner has not presented his claim to the state court and "has the right under the law of the State to raise, by any available procedure, the question presented"). Sometimes a state collateral proceeding is available yet the state law makes it predictable that the state court will hold the constitutional claim procedurally defaulted. In Engle v. Isaac, 456 U.S. 107, 125-26 n.28 (1982), for example, the Court allowed the petitioner to avoid the seemingly empty formality of filing in state court and receiving the predictable judicial opinion. In Harris, Justice O'Connor wanted to make clear that when a habeas petitioner proceeded directly to federal court in this manner, there would be no basis for requiring a "plain statement" of the default. 489 U.S. at 269-70 (O'Connor, J., concurring).

Second, she wrote to correct Justice Blackmun's characterization of the escape from procedural default announced in Murray v. Carrier, 477 U.S. 478 (1986), and Smith v. 
Warren Lee Harris, convicted of murder in an Illinois state court, petitioned for postconviction relief, also in the state system, asserting his Sixth Amendment right to the effective assistance of counsel and alleging that his trial counsel had failed to call alibi witnesses. The Illinois appellate court affirmed a dismissal of Harris's petition, stating that it is a "'well-settled" principle of Illinois law that 'those [issues] which could have been presented [on direct appeal], but were not, are considered waived." "49 The court noted that " 'except for the alibi witnesses,' petitioner's ineffective-assistance allegations 'could have been raised in [his] direct appeal," "50 and then went on to discuss the ineffective assistance of counsel claim on the merits. Harris then shifted to a federal habeas petition and faced the question of procedural default.

The Supreme Court applied the Long approach to procedural as well as substantive grounds and to habeas petitions as well as direct appeals. ${ }^{51}$ Examining the Illinois appellate court's opinion, the Court found no "clear[] and express[]" statement of reliance on the state law default, and declared that the federal habeas court could proceed. ${ }^{52}$ In a footnote, Justice Blackmun wrote that "perhaps" one could argue that the initial part of the Illinois court's opinion amounted to the needed clear statement, but that the fact that the Illinois court "went on to reject the federal claim on the merits" created the kind of ambiguity the Court had designed the Long presumption to solve..$^{53}$

Murray, 477 U.S. 527 (1986). Justice Blackmun had emphasized the "miscarriage of justice" language and failed to mention the requirement that the petitioner show his probable innocence, a point Justice O'Connor viewed as crucial. Harris, 489 U.S. at 270-71. It will be noted that the "miscarriage of justice" emphasis, as opposed to "probable innocence," has a closer connection to inaximizing the enforcement of rights, and is thus consistent with Justice Blackmun's approach to normative federalism.

49. 489 U.S. at 258 (quoting unpublished opinion at 12).

50. Id.

51. The Court had already expanded Long to procedural defaults in direct appeals that presented obstacles to Supreme Court review in Caldwell v. Mississippi, 472 U.S. 320, 327 (1985). Harris only extended Caldwell to habeas cases. One might have said after Caldwell that the Court could afford to take an expansive view of its own jurisdiction, since it would control any interpretations of federal law that inight emerge. Extending habeas corpus is quite another inatter, since it einpowers vast numbers of federal judges to issue opmions about the rights of the accused, far more than the Supreme Court could hope to control. Cf. Teague v. Lane, 489 U.S. 288 (1989) (arguably designed to control the role of lower federal courts in interpreting federal constitutional rights).

52. Harris, 489 U.S. at 266.

53. Id. at 266 n.13. 
Justice Kennedy argued for a presumption against jurisdiction, ${ }^{54}$ emphasizing the decision in Sykes "to honor state procedural defaults" 55 and "to accord appropriate respect to the sovereiguty of the States in our federal system. "56 Justice Kennedy's belief that the majority had taken a "miserly" account of the state's interests and had failed to give federalisin its due seems to suggest the sort of "empty" or "States' rights" form of federalism that does not fit the theory of normativity identified in this Article. Significantly, Justice Kennedy dissented alone. ${ }^{57}$

\section{Justice O'Connor's Restriction of the Independent and Ade- quate State Ground in Coleman}

In Coleman v. Thompson, ${ }^{58}$ Justice O'Connor did not write about the importance of the supremacy of federal law as she had in Long, though she did balance federal interests against state interests. ${ }^{59}$ On the federal interest side of the metaphorical scale, the federal courts needed an efficient way to determine whether they have jurisdiction. Long had constructed a presumption favoring federal jurisdiction in order to save the federal courts "the costs of excessive inquiry": ${ }^{\prime 0}$ They would not need to puzzle over the meaning of a confusing discussion of federal and state law, but would simply assume what was most likely-i.e., that there was no independent and adequate state ground. The state may still rebut the presumption by making a clear statement. But the presumption does not come into being in the first place without the "factual

54. Id. at 276-77 (Kennedy, J., dissenting).

55. Id. at 281 .

56. Id. (quoting Ulster County Court v. Allen, 442 U.S. 140, 154 (1979)).

57. Chief Justice Rehnquist and Justice Scalia joined both Justice Blackmun's and Justice O'Connor's opinions. Justice Stevens also wrote a concurring opinion to explain his vote in view of his dissent in Long. His position, as one might expect, expressed his theory of normative federalism: dissenting in Long and voting with the majority in Harris both tied to inaximizing individual rights.

58. 111 S. Ct. 2546 (1991).

59. Interests were balanced in Long also. There, Justice O'Connor noted the state's interests in consistent treatment of ambiguous opinions by the Supreme Court and in controlling imterpretations of state law and on the other hand, the federal interest in a reliable means of disposing of the jurisdictional question, in avoiding advisory opinions, and in the uniformity of federal law. Michigan v. Long, 463 U.S. 1032, 1038-41 (1983). She viewed making a clear statement as an easy enough feat for the state courts, which sinultaneously accoinodated the state's imterests and served the federal interest.

60. Coleman, $111 \mathrm{~S}$. Ct. at 2550. 
predicate" of a confusing mixture of state and federal law. And here in Coleman, the state court's minimal order responding to a limited motion did not "fairly appear[] to rest primarily on federal law, or to be interwoven with the federal law." 1 The state court had taken over five months to decide the motion, the parties had argued the merits, and Coleman was a citizen who claimed constitutional rights and faced death; none of these facts amounted to the requisite "factual predicate." And without the factual predicate, the basis for the presumption evaporated.

The presumption served the federal interest in efficiency because it spared a federal court from the task of figuring out exactly what the state court meant. But it also forced the federal court to spend time addressing the merits. Nevertheless, the Long Court had rejected the alternative of presuming against jurisdiction-which would have saved even more time-because of the importance of the supremacy of federal law. ${ }^{62}$ But now in Coleman, Justice O'Connor simply noted that without the factual predicate of muddled law, the probabilities changed and the presumption was no longer justified. She said nothing of the supremacy of federal law this time and characterized federal interests only in terms of efficiency. ${ }^{63}$ And, certainly, disposing of a habeas peti-

61. Id. at 2556 (quoting Long, 463 U.S. at 1040-41).

62. The importance of the supreinacy of federal law was the Court's stated reason (along with likelihood) for choosing the more time-consuming version of the presumption. Long, 463 U.S. at 1041. A more cynical interpretation is possible. In the setting of Long, which addressed whether the Supreme Court could hear the case, only the state, and not the accused, could benefit. Long addressed the problem of state courts using substantive state law rights and mixing thein with a discussion of the analogous federal right. The problem of mixing the state and federal law regarding analogous substantive rights was much more severe, since a state court writing about, say, unreasonable searches and seizures, might very naturally fail to be precise about the source of a right traceable to two different bodies of law. The state court might never make it clear whether it views state constitutional law as independent from federal law, as it has the power to do but may not choose to do, or whether it interprets state law analogues as inevitably mirror images of the federal rights. The accused would never use the presumption in applying to the Supreme Court. If the state court gave an expansive interpretation to rights, the accused will have won below and will not seek Supreme Court review. If the state court gave a narrow interpretation to rights, and the accused does seek review, it would mean that the state court did not rely on procedural state law grounds, which could result in a loss for the accused and a consequent desire to rely on the presumption in favor of state law. To the extent that the Long presumption was extended to procedural grounds and to habeas corpus (never initiated by the state), see Harris v. Reed, 489 U.S. 255 (1989) (joined by all Justices who participated in Long, with only Justice Kennedy dissenting), the cynical view of Long is undermined.

63. Justice Blackmun, in dissent, called attention to this shift: "Nor does the inajority 
tion on the basis of a procedural default is more efficient than deciding it on the merits. Seen this way, there was no federal interest at all in intruding on the state's sovereignty.

On the other side of the scale lay the state's interest in its sovereignty. Here, the matter of who "the state" really is creates a bit of a conundrum. ${ }^{64}$ One might imagine the state court as the entity that might command deference. As Justice O'Connor put it: "State courts presumably have a dignitary interest in seeing that their state law decisions are not ignored by a federal habeas court ...."65 Yet one could easily respond, "Then all they need to do is make a clear statement that they rely on state law; if they can't manage that, they don't deserve deference." But when O'Connor used the term "the State" in Coleman, she meant the prosecution. The state court might not care enough about its "dignitary interest" to take the easy step needed to avoid review: Overcrowded or "insufficiently motivated" state courts may fail to give "the State"- that is, the prosecution-the clear statement it needs to avoid habeas relitigation. "66 "The State" stands by helplessly as it must bear the costs of "uncertainty and delay."

even allude to the 'important need for uniformity in federal law', which justified this Court's adoption of the plain-statement rule in the first place." Coleman, $111 \mathrm{~S}$. Ct. at 2569 (quoting Long, 463 U.S. at 1040) (citation omitted).

64. For a discussion of Long in light of this conundrum, see Ann Althouse, How to Build a Separate Sphere: Federal Courts and State Power, 100 HARV. L. REv. 1485, 1537-38 (1987).

65. Coleman, 111 S. Ct. at 2559.

66. Id.

67. Id. Justice Blackmun wrote that "[t]he majority appears most concerned with the fmancial burden that a retrial places on the States," and, having limited the state's interest, observed that "if the initial trial conformed to the mandate of the Federal Constitution, not even the most probing federal review would necessitate a retrial." Id. at 2579 (Blackmun, J., dissenting). In other words, if the state follows the U.S. Constitution, it faces no costs. He oversimplified. First, the state may be said to suffer from "uncertamty" or lack of finality. It must continue to litigate the case and remain prepared to retry it even when the ultimate result will be a determination that no rights were violated. Second, even a state court that earnestly tries to comply with all applicable federal rights will fail to achieve complete congruency with the federal courts' view of the scope of those rights. Thus, one camot disregard the state's interests solely on the ground that the judges are not scrupulous enough. Finally, the burden of retrial is not a mere "fimancial burden." Years after the crime a case becomes imcreasingly difficult and sometimes impossible to try. Memories fade, witnesses die or move away to parts unknown. Retrial is no mere expenditure of dollars (which always seems small on paper compared with constitutional rights): It places the prosecution at a serious disadvantage in attempting to meet its burden of proof. 
Balancing state and federal interests, the outcome is obvious. If the presumption would not save the federal courts any time, there is no weight at all on the federal interest side. The metaphorical scale clunks down on the state interest side. ${ }^{68}$ In weighing efficiency against uncertainty and delay, Justice O'Connor had nothing to say about the constitutional rights of the criminally accused or about any other individual citizens. The only potential beneficiaries of federalism were the federal judges. The only cost to be avoided was wasted time. Coleman, seemingly the central character in the struggle, faded into the background; and the ultimate cost he would incur, death, was never placed on the scale at all.

68. Once saddled with the procedural default, Coleman had to establish "cause" as required by Sykes and its progeny. The only available theory was the ineffective assistance of counsel argument. As provided in an earlier opinion of Justice O'Connor's, Murray v. Carrier, 477 U.S. 478, 488 (1986), to amount to "cause" the counsel's behavior would have to be "constitutionally ineffective under the standard established in Strickland v. Washington," 466 U.S. 668 (1984). But because the default occurred in the state postconviction proceeding, where there is no constitutional right to an attorney, even in capital cases, Coleman, 111 S. Ct. at 2566 (citing Pennsylvania v. Finley, 481 U.S. 551 (1987); Murray v. Giarratano, 492 U.S. 1 (1989)), according to the majority, it was impossible to show ineffective assistance of counsel. Id. (citing Wainwright v. Torna, 455 U.S. 586 (1982)).

One might have thought, and indeed Coleman argued, that Carrier referred to Strickland only to describe how poor attorney's behavior needed to be before it could amount to "cause." The Carrier Court used the Strickland test to distinguish the lawyer froin the client-to determine when the lawyer's mistake is an "external" factor. Id. It is hard to see how such reasoning connects to the issue of when the Constitution affords a right of counsel, and the Coleman majority's eagerness to make that connection is truly chilling in a death penalty case. As Justice O'Connor attempted to explain this point, attorney error that does not violate the constitutional right to counsel is not cause because it cannot be "imputed to the State." Coleman, 111 S. Ct. at 2567 (quoting Carrier, 477 U.S. at 488 ). If "the State has no responsibility to ensure that the petitioner was represented by competent counsel," then, "[a]s between the State and the petitioner, it is the petitioner who must bear the burden of a failure to follow state procedural rules." Id. Carrier had emphasized the issue of whether the attorney's behavior was "external to the defense," but in Coleman's narrow view, "external to the defense" meant attributable to the state. Coleman also pointed to constitutional caselaw that gives an indigent criminal defendant "a right to appointed counsel in his first appeal as of right in state court" and a right to "effective assistance of counsel" for this "one and only appeal." Id. at 2568; see Douglas v. California, 372 U.S. 353 (1963). But Justice O'Connor regarded the two-day evidentiary hearing in the state collateral proceeding as that "one and only appeal." $111 \mathrm{~S}$. Ct. at 2568 . Justice Blacknun, in dissent, called O'Connor's argument "a sleight of logic that would be ironic if not for its tragic consequences." Id. at 2576 (Blackmun, J., dissenting). 
D. Justice Blackmun's Rebuke: The Demand for Normative Federalism

Justice Blackmun took issue with the majority's approach, which, in his words, "proceed[ed] as if the sovereign interests of the States and the Federal Government were co-equal."69 "Ours, however, is a federal republic, conceived on the principle of a supreme federal power and constituted first and foremost of citizens, not of sovereign States." ${ }^{\text {70 }}$ In the view of the dissent, because federal habeas corpus enforces supreme federal rights belonging to individual citizens, it "exemplifies the full expression of this Nation's federalism." 1 The majority's dutiful deference in the name of federalism was really an "abdication" that defied the real meaning of federalism. Federalism is a structure for "the diffusion of power," "a device"72 that must work toward a desirable end. In a proper view of federalism, the states themselves never become the objects of protection; they are a means for securing liberty and justice for the only proper objects of protection, the citizens. Although asserting that federalism lacks "inherent normative value," ${ }^{73}$ Justice Blackmun assigns it a normative value, with due

69. Coleman, 111 S. Ct. at 2570 (Blackmun, J., dissenting). Note that the use of the term "co-equal" suggests the equation of federalism and separation of powers, as discussed supra text accompanying notes 120-28, 165-69.

70. 111 S. Ct. at 2570 .

71. Id.

72. Id.

73. Id. at 2569 . 
citation to The Federalist Papers, ${ }^{74}$ to dispe] the impression that he is simply choosing his own preferred goal. ${ }^{75}$

Far from embracing the appropriate normative value, the majority had gone out of its way, according to Blackmun, to

74. Id. at 2570 (citing THE FEDERALIST No. 51, supra note 2, at 324 (James Madison) ("Justice is the end of government. It is the end of civil society.")). Justice Blackmun also cited Justice Brennan's highly influential and oft-cited article. Brennan's article clearly presented a theory of normative federalism:

We prize our federalism because of the proved contributions of our federal structure towards securing individual liberty. The distribution of the powers of government among many repositories is a sure guarantor against the tyranny and oppression which so often results from undue concentration of power. But the Federal Constitution also provides protections for the individual against excesses by any repository of power. The procedural safeguards for the individual prosecuted by a State for offenses against its laws are among these. The state judiciaries, responsible equally with the federal courts to secure these rights, should be encouraged to vindicate them. A self-fashioned abdication by the federal courts of their habeas corpus jurisdiction in cases where state prisoners are denied state relief because of procedural defaults would not provide that encouragement. On the other hand, an awareness by state tribunals that the procedural barrier to state review would not be deemed necessarily a barrier to federal review, would provide an incentive for state courts to reach serious constitutional claims and vindicate them in proper cases. Federalism is a device for realizing the concepts of ... liberty and justice lying at the base of all our civil and political institutions.

William J. Brennan, Jr., Federal Habeas Corpus and State Frisoners: An Exercise in Federalism, 7 UTAH L. REV. 423, 442 (1961).

75. The majority's view of federalism conceives of the states as the primary enforcers of federal law in criminal cases brought in their own courts. One can justify the majority's position even in terms of the dissent's "normative value" by arguing that it increases the likelihood that state courts will address federal rights in the first instance. For an extensive analysis of habeas corpus and other federal courts doctrine according to this principle, see Ann Althouse, Tapping the State Court Resource, 44 VAND. L. REv. 953 (1991). The majority's use of this principle is, however, shaky. For example, the majority says "it would be unseemly in our dual system of government for a federal district court to upset a state court conviction without an opportunity to the state courts to correct a constitutional violation." Coleman, $111 \mathrm{~S}$. Ct. at 2555 (quoting Rose v. Lundy, 455 U.S. $509,518(1982))$. This scarcely suggests that the point of deference is to maximize the enforcement of rights at the earliest and most efficient stage. Rather, the Court seems to believe that it would be in bad taste to intrude too abruptly. See AMERICAN HeRTTAGe Dictionary 1404 (New College ed. 1976) (defining "unseemnly" as "not in good taste; indecorous; unbecoming"). Federalism, tellingly called "comity," seems to be a matter of politesse and decorum. This sort of talk understandably draws a hostile response froun the members of the Court who have taken a more vigilant stance toward the protection of constitutional rights. A recent analysis of the Court, directed at laymen, made short work of the Coleman case. Citing the first line-"This is a case about federalism"-the author translated: "'Federalism' is known more commonly as 'states' rights,' and O'Connor believes in states' rights. A former state judge, she has seen no reason why federal judges have to look over the shoulder of state judges." DAvID G. SAVAGE, TURNING RIGHT: THE MAKING OF THE REHNQUisT SUPREME COURT 414 (1992); $c f$. Younger v. Harris, 401 U.S. 37 (1971) ("'Our Federalism' . . . does not mean blind deference to 'States' Rights' ....."). 
"creat[e] a Byzantine morass of arbitrary, unnecessary, and unjustifiable impediments to the vindication of federal rights . ..."76 The majority "display[ed] obvious exasperation" with the "expansive protection" the Constitution gives criminal defendants and "continue[d] its crusade to erect petty procedural barriers in the path of any state prisoner ...." A "functional dialect of interests" stood in for the proper "discourse of rights," as the majority "subordinate[d] fundamental constitutional rights to mere utilitarian interests."

\section{JUSTICE O'CONNOR'S THEORY OF NORMATIVE FEDERALISM: THE INDIVIDUAL CITIZEN AS INTEGRATED MEMBER OF THE ELECTORATE}

In Coleman, Justice Blackmun expressed the thesis that federalism must relate to the furtherance of individual rights. This thesis has a particularly strong connection to habeas corpus, which creates a tension between state and federal courts and which must invariably include an individual citizen who asserts constitutional rights. ${ }^{79}$ But notions of federalism extend beyond the field of habeas corpus and beyond jurisdictional boundaries between the state and federal courts. When the question is the extent of congressional power as against the state, and a single individual's life or liberty is no longer the focal point, Justice Blackmun's theory loses force. Then, as we shall see, Justice Blackmun, like the other Justices who vote with him on habeas issues, tends to shift away from the individual rights model of federalism to a simple validation of national supremacy. ${ }^{80}$ But it is in this context that Justice O'Connor's federalism takes on a normative quality, emphasizing benefits to individual citizens. Her democratic approach to federal-

76. Coleman, $111 \mathrm{~S} . \mathrm{Ct}$. at 2569.

77. Id.

78. Id. at 2572-73.

79. Justice Brennan's classic article, so frequently cited for the rights-oriented version of normative federalism, deals entirely with habeas corpus. See Brennan, supra note 74.

80. A federal supremacy theory could also be used to explain the liberal Justices' position in the habeas corpus cases. Their doctrinal choices regarding habeas tend to ensure that a federal court's intcrpretation of federal law will be imposed on state courts in criminal cases. More flexible acceptance of state court diversity in defining rights is not tolerated. Cf. Antonin Scalia, The Rule of Law as a Law of Rules, 56 U. CHI. L. REV. 1175, 1186 (1989) (suggesting acceptance of "tolerable diversity" in state court intcrpretation of federal law, particularly where clear rules are not possible). 
ism, perceptible between the lines of Long, ${ }^{81}$ becomes explicit as she discusses Congress's power to force the state into taking action on the issue of disposing nuclear waste in New York v. United States. $^{82}$

This Part first examines National League of Cities v. Usery ${ }^{83}$ and Garcia v. San Antonio Metropolitan Transit Authority, ${ }^{84}$ key cases in the development of substantive federalism. These cases outline a conflict that persists to this day. In particular, Justice Blackmun is central to this conflict, for it was his change of position that provided a majority for overruling National League of Cities in Garcia. Justice Blackmun also wrote the opinion in Garcia. This Part then examines Gregory v. Ashcroft, ${ }^{85}$ a 1991 opinion authored by Justice O'Connor, who had dissented in Garcia and predicted a return to judicial "responsibility" in enforcing the principles of federalism. Gregory presented an opportunity to return to National League outright, but the Court did not take this opportunity. In Justice O'Connor's Gregory opinion, we see the beginnings of her democratic theory of normative federalism, which comes to fruition in New York v. United States. Finally, this Part analyzes New York $v$. United States and its implications in depth.

\section{A. Background: National League of Cities and Garcia}

In National League of Cities $v$. Usery, ${ }^{86}$ the Court struck down the application of the Fair Labor Standards Act (FLSA) ${ }^{87}$ to the states and took the position that the Constitution's intended federal structure-whether explicit in the Tenth Amendment or somewhere inherent in the limited powers of the rest of the document-posed an affirmative limitation to the powers of Congress

81. See supra text accompanying note $26-41$.

82. 112 S. Ct. 2408 (1992).

83. 426 U.S. 833 (1976), overnuled by Garcia v. San Antonio Metro. Transit Auth., 469 U.S. 528 (1985).

84. 469 U.S. 528 (1985).

85. 111 S. Ct. 2395 (1991).

86. 426 U.S. 833 (1976), overruled by Garcia v. San Antonio Metro. Transit Auth., 469 U.S. 528 (1985).

87. Under the Fair Labor Standards Amendments of 1966, Congress extended the FLSA to virtually all state and local government employees and withdrew minimum wage and overtime exemptions from public hospitals, schools, and mass transit carriers whose rates and services were subject to state regulation. 
defined in Article I. Thus, although the commerce power had long been proclaimed "plenary," Congress could not exercise the commerce power in a way that violated federalism any more than it could exercise the commerce power in a way that violated equal protection or due process.

Less than a decade later, in Garcia v. San Antonio Metropolitan Transit Authority, ${ }^{89}$ the Court overruled National League of Cities. It no longer would judicially enforce any affirmative limitation on Congress. The constraint of federalism would have to arise from within Congress itself. The courts simply could not do a good enough job of demarcating the elusive meaning of federalism, which under National League of Cities entailed the identification of "traditional state functions." For those concerned that federalism had come to mean nothing of any substance-a mere "weak 'essence" in Justice O'Connor's critical words" - the Garcia Court drew attention to the supposed representation of the states in Congress. The Court's shift within such a short time is explainable: Not only had judicial experience accrued, but the shift only involved one Justice. National League of Cities had been decided by a 5-4 vote; Garcia was decided by the same vote. Justice Blackmun, who was to author the Coleman dissent excoriating the majority for its "empty federalism," alone changed sides. He had provided the fifth vote in National League of Cities through a separate concurrence, in which he worried about "certain possible implications" of the decision. ${ }^{91}$ Writing in Garcia, and referring to his National League concurrence, he concluded that the Court had "underestimated ... the solicitude of the national political process for the continued vitality of the States."

The rest of the erstwhile National League of Cities majority wrote biting dissents. Justice Powell methodically critiqued the assumption that Congress represents the states. ${ }^{93}$ Justice O'Connor, as well as then-Justice Rehnquist, predicted a return to National League of Cities. In Justice O'Connor's words, "[I] share

88. See, e.g., Heart of Atlanta Motel v. United States, 379 U.S. 241, 258 (1964); Wickard v. Filburn, 317 U.S. 111, 124 (1942); United States v. Darby, 312 U.S. 100, 114, 118 (1941).

89. 469 U.S. 528,557 (1985).

90. Id. at 580 (O'Connor, J., dissenting).

91. 426 U.S. at 856 (Blackmun, J., concurring).

92. 469 U.S. at 557.

93. Id. at 564-65 (Powell, J., dissenting). 
Justice Rehnquist's belief that this Court will in time again assume its constitutional responsibility." 94 Two members of the Garcia majority (Justices Brennan and Marshall) have now retired, ${ }^{95}$ replaced by Justices more likely to vote with the Garcia dissenters-yet the Court has not revived National League of Cities. We must therefore consider whether Justice O'Connor, who has become the Court's spokesperson on issues of federalism, has defined some other way for the Court to "assume its constitutional responsibility."

Justice Blackmun, in overruling National League, minimized, but did not wholly exclude, the judicial role in reviewing congressional impositions on the states. Although courts would need to restrain themselves and leave protection of the states to Congress, the adequacy of congressional procedure would remain judicially reviewable:

[T] he fundamental limitation that the constitutional scheme imposes on the Commerce Clause to protect the "States as States" is one of process rather than one of result. Any substantive restraint on the exercise of Commerce Clause powers must find its justification in the procedural nature of this basic limitation, and it must be tailored to compensate for possible failings in the national political process rather than to dictate a "sacred province of state autonomy."

Justice Blackmun still expressed a belief in the states' "special and specific position in our constitutional system." 97 Even though "the scope of Congress' authority under the Commerce Clause must reflect that position," Justice Blackmun thought that such a limitation would tend to be self-enforcing and "inherent in all congressional action." ${ }^{98} \mathrm{He}$ rejected persistent judicial intermeddling because " $[t]$ he political process ensures that laws that unduly

94. Id. at 589 (O'Connor, J., dissenting).

95. One member of the dissenting group, Chief Justice Warren Burger, has also retired, replaced by Justice Scalia, who inoved into Justice Rehnquist's seat when Rehnquist became Chief Justice. One would expect Justice Scalia to vote, like Burger, with the Garcia dissenters. Justice $O^{\prime}$ Connor, replacing Justice Potter Stewart, entered the Court after National League (in which Stewart had joined the majority opinion) and before Garcia.

96. Garcia, 469 U.S. at 554 (quoting EEOC v. Wyoming, 460 U.S. 226, 236 (1983)).

97. Id. at 556.

98. Id. 
burden the States will not be promulgated." 99 Yet his judicial restraint was not ironclad, for he went on to reject a judicial role "[i]n the factual setting of these cases" where "the internal safeguards of the political process have performed as intended."100 He thus left open the argument that if, in some other factual setting, litigants could show that the political process had not "performed as intended," the courts ought to reactivate themselves. Of course, the Garcia dissenters were ready to make a blanket finding that the political process did not perform as intended, but, even within the majority's mode of analysis, states could conceivably win isolated victories by demonstrating some flaw in the process.

Examining the political process for failings is scarcely an easy method of analysis, however. It forces the courts out of a position of restraint and asks them to examine the asserted shortcomings and prejudices of Congress. Nevertheless, this approach made sense within the majority's reasoning. Garcia rejected the contention that courts had any basis for second-guessing Congress about what immune enclave ought to be left to the states and justified entrusting Congress with this decision by professing a belief in Congress's representation of the states and their interests. To examine the political process is simply to remain vigilant about whether the conditions that warranted judicial restraint continue to exist.

The Younger doctrine provides a helpful analogy. ${ }^{101}$ This doctrine of restraint, which prevents the federal courts from enjoining ongoing state proceedings and leaves the disposition of federal constitutional defenses to the state courts, is premised on the theory that the state courts are adequate to the task. ${ }^{102}$ But although federal courts do not routinely intervene under the Younger doctrine, they do routinely consider whether the state courts have the capacity to perform the task entrusted to them. ${ }^{103}$ Similarly, under Garcia, along with restraint comes an ongoing obligation to assess the validity of that restraint. The

\footnotetext{
99. Id.

100. Id.

101. See Younger v. Harris, 401 U.S. 37 (1971).

102. Younger and its progeny elaborate exceptions in terms of "bad faith," "harassment," and so on, but all of these exceptions can be boiled down to the lack of an adequate ongoing state proceeding. For a complete examination of this point, see Althouse, supra note 75 , at $999-1004$.
}

103. Id. at $997-98$. 
courts defer to other institutions because there is some benefit to be gained when they are left alone "to perform their separate functions in their separate ways."104

Just as Younger did not advocate "blind deference" to the states, ${ }^{105}$ Garcia does not advocate "blind deference" to Congress. The judicial role shifts from redoing the work of the other institution to assessing the adequacy of the other institution. ${ }^{106}$ Ground for dispute among the Justices remains nevertheless. Some might embrace the notion of congressional representation of the states as a truth-decided once and for all, petrified into a legal fiction-and not subject to case-by-case reexamination. Those who always doubted Congress's responsiveness to state interests might readily perceive a failure in the political process; and thus the Court may return to its "constitutional responsibility" without the unsettling spectacle of yet another overruling. The Garcia dissenters can reach their goal far more gracefully by taking Garcia's own principle of representation and applying it seriously. ${ }^{107}$

\section{B. Preserving Garcia with a Clear Statement Rule: Gregory v. Ashcroft}

1. Background. In Gregory v. Ashcroft, ${ }^{108}$ Ellis Gregory, Jr. and Anthony P. Nugent, Jr., Missouri state judges, sued to challenge a provision of the state constitution that required judges to retire at age seventy. ${ }^{109}$ They argued that the provision violat-

\section{Younger, 401 U.S. at 44.}

105. Id.

106. The law of habeas corpus also yields a useful comparison. The Warren Court, in the wake of Brown v. Allen, 344 U.S. 443 (1953), defined the role of the federal courts as one of simply redoing the work of the state courts. Some of the work of the Burger and Rehnquist Courts can be characterized as a shift to an assessment of whether the state court was adequate. See Stóne v. Powell, 428 U.S. 465 (1976). The Court rejected an attempt to make this the sole guiding principle in habeas, and Stone has remained limited to Fourth Amendment exclusionary rule issues. Wright v. West, 112 S. Ct. 2482 (1992). (Notably, Justice O'Cormor dissented.) The Court has, however, granted certiorari in a case presenting the question whether Stone ought to be extended to Miranda violations. See Williams v. Withrow, 944 F.2d 284 (6th Cir. 1991), cert. granted, 112 S. Ct. 1664 (1992) (No. 91-1030).

107. By the same token, cases like Younger and Stone v. Powell, 428 U.S. 465 (1976), could be turned to opposite effect if federal courts were willing to scrutinize the operations of the state courts and openly declare them inadequate.

108. 111 S. Ct. 2395 (1991).

109. Id. at 2398 (citing MO. CoNST. art. V, \& 26). They sued John D. Ashcroft, the Governor of Missouri, filing their claim in the federal district court for the Eastern Dis- 
ed the federal Age Discrimination in Employment Act $(A D E A)^{110}$ and equal protection as guaranteed by the federal Constitution. ${ }^{111}$ The key question was whether the federal age discrimination statute included state judges. Congress had amended the ADEA specifically to include employees of the states, ${ }^{112}$ but the statute's definition of "employee" excluded those appointed "on the policymaking level."113 The majority of the Supreme Court, like the federal courts below, determined that state judges were excluded from coverage. It should strike the reader as somewhat extraordinary that Justice O'Connor, the author of the opinion, Chief Justice Rehnquist, and Justices Scalia, Kennedy, and Souter accepted the categorization of judges as policymaking employees. ${ }^{114}$ One might have expected advocates of judicial restraint to agree with the petitioner that "judges merely resolve factual disputes and decide questions of law; they do not make policy." 115 Indeed, Justice White, in dissent, took that position. ${ }^{116}$

trict of Missouri. Id.

110. Pub. L. No. $90-202, \S 2,81$ Stat. 602 (1967) (codified as amended at 29 U.S.C. §§ 621-634) (1988)).

111. U.S. CoNST. amend. XIV.

112. 29 U.S.C. $\S 630(\mathrm{~b})(2)(1988)$.

113. Id. \& 630(f) (amending definition of "employee" to exclude "any person elected to public office in any State or political subdivision of any State by the qualified voters thereof, or any person chosen by such officer to be on such officer's personal staff, or an appointee on the policymaking level or an immediate adviser with respect to the exercise of the constitutional or legal powers of the office"), quoted in Gregory, $111 \mathrm{~S}$. Ct. at 2403.

114. Governor Ashcroft, the defendant-appellee, argued outright that judges were "policymakers," noting the creativity inherent in the common law process. Gregory, 111 S. Ct. at 2403. Examiming this position, the Court quoted Justice Oliver Wendell Holmes at length:

The very considerations which judges most rarely mention, and always with an apology, are the secret root from which the law draws all the juices of life. I mean, of course, considerations of what is expedient for the community concerned. Every important principle which is developed by litigation is in fact and at bottom the result of more or less definitely understood views of public policy; most generally, to be sure, under our practice and traditions, the unconscious result of instinctive preferences and inarticulate convictions, but nonetheless traceable to views of public policy in the last analysis.

Id. at 2404 (quoting OLIVER W. HOLMES, JR., THE COMMON LAW 35-36 (1881)).

115. Id. at 2403.

116. Id. at 2412 (White, J., concurring in part, dissenting in part, and dissenting in the judgment). Justice White, joined by Justice Stevens, rejected the clear statement rule that the majority used to avoid deciding whether judges are "policymakers." According to White, "it is clear that the decisionnaking engaged in by common-law judges, such as petitioners, places them 'on the policymaking level.'" 
Although she took the position that the Constitution requires a balance of state and federal powers, Justice O'Connor avoided restoring National League of Cities's immune enclave for the states. She did, however, resurrect special treatment for congressional incursions into areas traditionally regulated by the states. Instead of forbidding Congress to legislate in these areas, she created a presumption against the interpretation that Congress has decided to exercise its admitted power and intrude upon the states. Congress must make a "clear statement" of its intent to include the state in a statute regulating matters "traditionally" left to the states. ${ }^{117}$

In Gregory, following this clear statement rule, the Court held that the ADEA did not apply to judges. Even though the statute expressly referred to employees of the state, a category that certainly includes state judges, it went on to exclude some state employees. While "policymaking" is not the most apt expression to use to identify judges, the exclusion at least arguably included judges, thus depriving the "employees" category of the necessary clarity.

117. Id. at 2401 (citing Will v. Michigan Dep't of State Police, 491 U.S. 58, 65 (1989) (citing United States v. Bass, 404 U.S. 336, $349(1971)$ )). Will held that the states are not "persons" within the meaning of 42 U.S.C. $\$ 1983$. Will, 491 U.S. at 65-67. Quern v. Jordan, 440 U.S. 332 (1979), had already determined that the states could not be sued in federal court using $\S 1983$ because of the Eleventh Amendment. Id. at 339-45. Even though Congress has the power to abrogate the states' Eleventh Amendinent immunity, it would need to do so explicitly. Id. at 340 . Indeed, the degree of explicitness required has increased since Quem. Most notably, in Atascadero State Hospital v. Scanlon, 473 U.S. 234 (1985), the Court devised a "clear statement" rule to determine whether Congress had abrogated Eleventh Amendment immunity: In order to abrogate, Congress would need to make its intention "unmistakably clear in the language of the statute." Id. at 242. In Will, the majority rejected arguments that $\S 1983$, as a major product of Reconstruction, ought to be read as a component of that era's alteration of the federal-state balance decidedly in favor of the national government. 491 U.S. at 68-70. Will expanded "clear statement" analysis beyond the Eleventh Amendment context: "[I]f Congress intends to alter the 'usual constitutional balance between the States and the Federal Government,' it must make its intention to do so 'unmistakably clear in the language of the statute.' Id. at 65 (quoting Scanlon, 473 U.S. at 242). Congress should make its intention "clear and manifest" if it intends to preempt the historic powers of the States. Rice v. Santa Fe Elevator Corp., 331 U.S. 218, 230 (1947); see also id. ("In traditionally sensitive areas, such as legislation affecting the federal balance, the requirement of clear statement assures that the legislature has in fact faced, and intended to bring into issue, the critical matters involved in the judicial decision." (quoting United States v. Bass, 404 U.S. 336,349 (1971)). 
2. The Problem of Returning to "Traditional" State Functions. Garcia had overruled National League of Cities in part because of the difficulty of determining which traditional functions could not be reached by Congress. The Gregory dissenters criticized the majority's reinstatement of the very line-drawing problem that had made National League of Cities so unworkable in practice. ${ }^{118}$ Yet the similarity between National League of Cities and Gregory should not be overstated. Under National League of Cities, the line-drawing was crucial: Either Congress could reach the states or it was absolutely barred. Congress might pass a statute, uncertain as to whether a court at some later date would void it, and unable to take any step to avoid this uncertainty. Alternatively, Congress might decline to apply a statute to the states and never know whether it could validly have done so.

Gregory, on the other hand, merely demands explicitness when including the states. Congress would not need to worry about which side of a judicially drawn line a particular regulation fell. As soon as any question arose, it could solve it by making the statute explicit. Congress has no cognizable interest in writing ambignous statutes. Suppose that there were a statute that arguably reaches traditional state functions, but that ultimately will be found by the courts to fall outside of that limited sphere. Congress sacrifices nothing by making that statute explicit; on the contrary, it gains certainty and freedom from litigation.

One need scarcely wring one's hands over a little extra consideration of state interests. If extra consideration leads to a rejection of the application of a statute to the states, or if legislators shrink from approving of the statute simply because its application to the states becomes conspicuous, that rejection exemplifies the political protection of federalism values touted by Garcia. One should not criticize possible legislative "overenforcement" of federalism, the way one might criticize overexpansive judicial interpretations of constitutional provisions that constrain democratic choice. ${ }^{119}$ Courts strive for precise definition of rights-and an

118. See Gregory, 111 S. Ct. at 2410 (White, J., concurring in part, dissenting in part).

119. For a less sanguine appraisal, see Philip P. Frickey, Lawnet: The Case of the Missing (Tenth) Amendment, 75 MINN. L. REv. 755 (1991) (addressing the circuit court opinion in Gregory). Professor Frickey writes: "Federalism lives on, only now as an underenforced constitutional norm dressed up as a canon of statutory interpretation. In other words, the tenth amendinent got a new naine, fake papers, and diluted authority 
immune enclave for the states-in order to justify their role in enforcing them to the detriment of legislative enactments. In the political arena, no such precision is needed or even desirable. A legislature has many valid choices and may weigh interests within a wide range of possibilities. Assigning a great weight to states' interests is entirely appropriate and is consistent with the reasoning in Garcia. If federalism is to be left to political safeguards, then a political sort of regulation that does not resemble adjudication will necessarily result. The uncertainties and difficulties inherent in the meaning of "tradition," that seemed illegitimate and unworkable when wielded by judges, look quite different in the hands of legislators.

3. State Autonomy and Normative Federalism. Fundamental to Justice O'Connor's conception of constitutional structure im Gregory was the importance of the states, which she strikingly portrayed as coequal to the national government: "As every schoolchild learns, our Constitution. establishes a system of dual sovereignty between the States and the Federal Government."120 She quoted strong language from the nineteenth century, depicting the state as possessor of a separate sphere:

"'[T] government, and endowed with all the functions essential to separate and independent existence,' ... [.] '[W]ithout the States in union, there could be no such political body as the United States.' Not only, therefore, can there be no loss of separate and independent autonomy to the States, through their union under the Constitution, but it may be not unreasonably said that the preservation of the States, and the maintenance of their governments, are as much within the design and care of the Constitution as the preservation of the Union and the maintenance of the National government. The Constitution, in all its provisions, looks to an indestructible Union, composed of indestructible States."121

under the witness protection program." Id. at 760 .

120. Gregory, $111 \mathrm{~S}$. Ct. at 2399. She goes on to quote from Tafflin v. Levitt, 493 U.S. 455, 458 (1990): "We beg[a]n with the axiom that, under our federal system, the States possess sovereignty concurrent with that of the Federal Government, subject only to limitations imposed by the Supremacy Clause.'" 111 S. Ct. at 2399 (alteration in original).

121. 111 S. Ct. at 2399 (quoting Texas v. White, 74 U.S. (7 Wall.) 700, 725 (Dec. 
The autonomy reserved for the states does not represent an empty deference. It is instrumental, designed to give "numerous benefits" to the people:

[D]ecentralized government ... will be more sensitive to the diverse needs of a heterogenous society; it increases opportunity for citizen involvement in democratic processes; it allows for more innovation and experimentation in government; and it makes government more responsive by putting the States in competition for a mobile citizenry. ${ }^{122}$

But individual liberty is "[p]erhaps the principal benefit" of federalism. ${ }^{123}$ Quoting Justice Powell's dissenting opinion in Garcia, Justice O'Connor asserted that the Framers mandated a " "balance of power' between the States and Federal Government" in order to protect "'our fundamental liberties." "224 She equated separation of powers and federalism: "Just as the separation and independence of the coordinate Branches of the Federal Government serves to prevent the accumulation of excessive power in any one Branch, a healthy balance of power between the States and the Federal Government will reduce the risk of tyranny and abuse from either front."125 Quoting from The Federalist Papers, she described the ideal conception of federalism: The state and federal governments "stand ready to check" each other's "usurpations" of

Term 1868) (quoting Lane County v. Oregon, 74 U.S. (7 Wall.) 71, 76 (Dec. Term 1868))). White held that the state of Texas could sue in federal court even though it had not yet been readmitted to the union after the Civil War. The Court rejected the argument that Texas had ceased to be a state through its act of secession, since the states, as well as the union, are "indestructible." Texas was thus able to sue and to recover securities its confederate government had sold.

122. Id. (citing generally Michael W. McConnell, Federalism: Evaluating the Founders' Design, 54 U. CHI. L. REv. 1484, 1491-511 (1987); Deborah J. Merritt, The Guarantee Clause and State Autonomy: Federalism for a Third Century, 88 Colum. L. REv. 1, 3-10 (1988)).

123. 'Id.

124. Id. at 2400 (quoting Atascadero State Hosp. v. Scanlon, 473 U.S. 234, 242 (1985) (quoting Garcia v. San Antonio Metro. Transit Auth., 469 U.S. 528, 572 (1985) (Powell, J., dissenting))).

125. Id. 
individual rights, ${ }^{126}$ thus giving the people a "double security" for their rights. ${ }^{127}$

Of course, the individual judges who brought the lawsuit asserted rights, and the approach taken by the majority narrowed the scope of the rights to be found in the ADEA. But Justice O'Connor's solicitude did not extend to the judges as rights-bearers. Indeed, the rule of statutory interpretation she announced had very little to do with the enforcement of rights by the federal judiciary. Rather, Justice O'Connor sought to preserve the vigor of the state as a political entity independent of Congress, on the theory that strong states would have the ability to protect their citizens from encroachments on their rights by the national government. Never mind that in this case the federal statute granted rights to individuals and that the state to be strengthened discriminated on the basis of age. Rather than siding with individual rights on a case-by-case basis, the Gregory Court adopted a long-range strategy. The Gregory Court chose to invigorate the states in a grand balance of power, trusting that over time benefits would flow to individuals. ${ }^{128}$

126. Id. (quoting THE FEDERALIST No. 28, at 181 (Alexander Hamilton) (Clinton Rossiter ed., 1961) ("Power being almost always the rival of power, the general government will at all tines stand ready to check the usurpations of the state governments, and these will have the same disposition towards the general government. The people, by throwing themselves into either scale, will infallibly make it preponderate. If their rights are invaded by either, they can make use of the other as the instrument of redress.")).

127. Id. (quoting THE FEDERALIST No. 51, supra note 2, at 323 (James Madison) ("In a single republic, all the power surrendered by the people is submitted to the administration of a single government; and the usurpations are guarded against by a division of the government into distinct and separate departments. In the coinpound republic of America, the power surrendered by the people is first divided between two distinct governments, and then the portion allotted to each subdivided among distinct and separate departments. Hence a double security arises to the rights of the people. The different governments will control each other, at the same time that each will be controlled by itself.")).

128. Justice $O^{\prime}$ Connor grounds her rule of statutory interpretation in the Constitution. See Hilton v. South Carolina Pub. Rys. Comm'n, 112 S. Ct. 560, 567 (1991) (O'Connor, J., dissenting). In Hilton, the Court relied on stare decisis to continue to hold states liable under the Federal Employers Liability Act (FELA), because the Act did not contain a clear statement of applicability to the states. The Court, though, did endorse the clear statement rule in the absence of stare decisis:

When the issue to be resolved is one of statutory construction, of congressional intent to impose monetary liability on the States, the requirement of a clear statement by Congress to impose such liability creates a rule that ought to be of assistance to the Congress and the courts in drafting and interpreting legislation. The requirement also serves to make parallel two separate inquiries into state liability: Eleventh Amendunent doctrine and canons of statutory interpretation. In most cases . . . the rule can be followed. The resulting symmetry, mak- 
4. Analyzing the Presumption. In Gregory, the Court set up a rule of statutory interpretation that assumes, in the absence of a clear statement to the contrary, that Congress does not intend to regulate areas traditionally left to the states. ${ }^{129}$ One might argue that Congress does not have the solicitous attitude toward the states that the presumption embodies: If Congress enacts a statute applicable to the states by ordinary canons of statutory interpretation, it probably means to impose on the states. Such an argument assumes that a presumption represents only an assessment of what

ing a State's liability or immunity, as the case may be, the same in both federal and state courts, has much to coninend it. It also avoids the federalism-related concerns that arise when the National Government uses the state courts as the exclusive forum to permit recovery under a congressional statute. This is not an inconsequential argument. Symmetry in the law is more than aesthetics. It is predictabihty and order. But symmetry is not an imperative that must override just expectations which themselves rest upon the predictability and order of stare decisis.

Id. at 566 .

Oddly enough, the case that commanded stare decisis, Parden v. Terminal Ry. of Ala. St. Docks Dep't, 377 U.S. 184 (1964), had already been overruled in part by Welch v. Texas Dep't of Highways \& Pub. Transp., 483 U.S. 468 (1987). Parden had held that the state's entering into the railway business, given the existence of FELA, constructively waived Eleventh Amendment immunity. 377 U.S. at 196. Welch pronounced the constructive waiver theory inconsistent with the clear statement approach to abrogation that had developed after Parden was decided. Respect and disrespect for Parden could coexist, according to the inajority in Hilton, because statutory law is different from constitutional law. Hilton, 112 S. Ct. at 564. The Court has a special obligation to ensure the correctness of constitutional interpretation, since Congress lacks the power to correct it (other than through the difficult process of constitutional amendment). Id. Statutory interpretation can, however, be corrected by subsequent congressional action. Id. Thus the Court justified overruling Parden to the extent that it gave rise to an alternative to abrogation, and thus, as the Court saw it, imterpreted the Constitution. Id. But because the interpretation of FELA to include the states took place at the statutory level, the Court could leave the precedent intact. Id. Justice O'Connor (joined by Justice Scalia) disagreed:

The clear statement rule is not a mere canon of statutory interpretation. Instead, it derives from the Constitution itself. The rule protects the balance of power between the States and the Federal Government struck by the Constitution. Although the Eleventh Amendment spells out one aspect of that balance of power, the principle of federalism underlying the Amendinent pervades the constitutional structure: The Constitution gives Congress only linited power to govern the Nation; the States retain power to govern locally .... Recognizing this basic truth about our governmental structure under the Constitution, we have been wary of extending the effect of congressional enactments into areas traditionally governed by the States, unless Congress has directed us to do so by an unmistakably clear statement .... Thus, the Court's position that we are not required to employ the clear statement rule in this context ignores the constitutional source of the rule.

Id. at 567-68 (O'Connor, J., dissenting) (citations onitted).

129. See supra text accompanying notes 117-19. 
is most likely. It will be remembered that Justice O'Connor used likelihood to explain both the presumption of Supreme Court jurisdiction in Michigan v. Long ${ }^{130}$ and the failure to presume habeas jurisdiction in Coleman v. Thompson. ${ }^{131}$ Indeed, in reality, a presumption is used for reasons that go beyond likelihood. Both Long and Coleman warrant reading beyond the proffered "likelihood" justification. Long strengthened the Supreme Court's power to control what it perceived as overreaching and democratically irresponsible behavior by the state courts. Coleman restricted the power of the lower federal courts to unsettle state convictions. Both decisions constrained the expansion of constitutional rights enforcement.

The presumption in Gregory similarly represents much more than a realistic estimate of congressional intentions. Rather, it is a mechanism to vitalize the state-federal power struggle, which the constitutional Supremacy Clause would otherwise make too onesided. Democratic principles further justify Justice O'Connor's choice. Although the judges who brought suit are rights-claimants, they are also agents of the state, capable of benefitting or oppressing the people of the state. The people, as the body politic, are the proper beneficiaries of federalism. ${ }^{132}$ Justice O'Connor therefore structured doctrine to enhance their control over their agents who serve in the state government. In Long, O'Connor displayed no regard for the autonomy of judges who cut off the power of the electorate. ${ }^{133}$ Similarly, Gregory preserved popular control over judges by making it difficult to use federal law to counter-

130. 463 U.S. 1032 (1983).

131. 111 S. Ct. 2546 (1991).

132. The difference between Justice Blackmun's conception of the beneficiaries of federalism and Justice O'Connor's corresponds to Suzanna Sherry's discussion of each Justice's overall vision and reasoning. See Sherry, supra note 8. Analyzing numerous opinions written by Justice O'Connor prior to Gregory, Professor Sherry characterizes the Justice's reasoning as feminine and contrasts it to the thinking of liberal Justices like Blackmun. Id. at 592-613. Sherry finds the classic liberal vision of individuals as atomistic rights-bearers inherently masculine and the classic republican emphasis on coinmunity and virtue inherently feminine. Id. at 590-91. Although the advisability of assigning broad philosophic positions and reasoning patterns to the two sexes remains a matter of serious dispute, the assignment of the republican position to O'Connor and the liberal position to Justices such as Blackmun has a great deal of explanatory power. I would, however, hesitate to characterize O'Connor as essentially feminine. How would one characterize allowing a man to go his death because he missed a filing deadline by three days as feminine?

133. See supra text accompanying note 43 . 
mand the state law choice to impose mandatory retirement on judges. ${ }^{134}$

In Gregory, Justice O'Connor placed particular emphasis on the state's power to constitute itself, to decide who will carry out its functions, and "to prescribe the qualifications of its officers and the manner in which they shall be chosen."135 She did not characterize this power as a mere "States' right"-a prerogative of the state simply because it is a state. She gave a normative federalism twist to it: "Such power inheres in the State by virtue of its obligation ... to preserve the basic conception of a political community." "136 To carry out its "power and responsibility," a state needs control over elective and "important nonelective executive, legislative, and judicial positions." formulation, execution, or review of broad public policy ... go[es] to the heart of representative government."138 This power is "reserved to the States under the Tenth Amendment and guaranteed them by that provision of the Constitution under which the United States 'guarantees to every State in this Union a Republican Form of Government.' "139 Justice O'Connor's deference to the states, then, is not "blind deference," 140 but deference to a democratically responsive, properly functioning governmental entity.

By the same token, deference to Congress is, under Gregory, deference to a governmental entity that functions as assumed in Garcia, taking account of the interests of the states. Just as Long's clear statement rule forced state judges to expose themselves to voter antagonism, Gregory forces Congress to make a show of its

134. Difficult, but not impossible: Federal law is still supreme. Popular attempts to control the judiciary in ways that violate the federal Constitution or federal statutes will still fail-though the federal statutes will be subject to the clear statement requirement.

135. $111 \mathrm{~S}$. Ct. at 2401 (quoting Boyd v. Nebraska ex rel. Thayer, 143 U.S. 135, 161 (1892)). When analyzing the judges' Fourteenth Amendment claim, which, of course, did not implicate the statutory clear statement rule, the Court accepted the state's choice of a set age as a method of protecting against incompetent judges. Despite the life tenure of federal judges, and the fact that several inembers of the Supreme Court exceed Missouri's age of competence, the state could generalize that competence declines with age. Even though a line drawn on the basis of age is crude and inaccurate, the state may rationally decide that the loss of some competent judges is outweighed by the difficulty of determining competence on an individual basis. See id. at 2407-08.

136. Id. at 2401 (quoting Dunn v. Blumstein, 405 U.S. 330,344 (1972)).

137. Id. at 2402 (quoting Dunn, 405 U.S. at 344).

138. Id. (quoting Dunn, 405 U.S. at 344).

139. Id. (quoting U.S. CoNST. art. IV, \& 4).

140. See supra text accounpanying notes 96-107. 
intent to impose a requirement on the states. According to Garcia's rationale for withdrawing judicial review, Congress represents the states' interests. Conspicuous inclusion of the states in the language of a proposed statute will alert members of Congress of the need to consider these interests. A statute that fails to mention the states but silently includes them in some broad definition of scope may not attract this scrutiny. It may not be until later, perhaps after the statute is enacted and litigation initiated, that the application to the states comes into question. At this point, it is too late for the political representation to take place in Congress. ${ }^{141}$

\section{Finding a Democratic Model for Normative Federalism: New York v. United States}

Michigan v. Long ${ }^{142}$ and Gregory v. Ashcroft, ${ }^{143}$ as we have seen, evidence Justice O'Connor's movement toward a normative theory of federahism. Nevertheless, when she wrote Coleman v. Thompson, ${ }^{144}$ the "case about federalism,"145 Justice O'Connor drew the stinging criticism from Justice Blackmun, who accused her of "blindly"146 deferring to states' interests. Justice Blackmun, it will be remembered, insisted that the Court should only employ notions of federalism to "secure[] to citizens the liberties that derive from the diffusion of sovereign power." 147 In a case decided one year after Coleman, Justice O'Connor responded to Blackmun by quoting his words and making them her own. It is at this point, in the case of New York v. United States, ${ }^{148}$ that O'Connor made her democratic theory of normative federalism explicit.

1. Background. In New York, the Court struck down the strictest portion of a federal statute addressing the disposal of low-

141. Conceivably but improbably, Congress might be so responsive to state interests that it would amend the statute to exclude the states.

142. 463 U.S. 1032 (1983).

143. 111 S. Ct. 2395 (1991).

144. 111 S. Ct. 2546 (1991).

145. Id. at 2552 .

146. Id. at 2569 (Blackmun, J., dissenting).

147. Id. at 2570 (1991); see supra Section I(D).

148. 112 S. Ct. 2408 (1992). 
level radioactive waste. The federal Low-Level Radioactive Waste Policy Act, ${ }^{149}$ proposed by the National Governors' Association, anticipated that the states would enter regional compacts designed around new disposal sites. ${ }^{150}$ But only nineteen states managed to enter compacts, and these formed only around the three existing sites. ${ }^{151}$ With no new sites planned, and thirty-one states facing exclusion from the three sites they had relied on in the past, the need for a brisker approach to motivation seemed clear. The state governors reached an agreement, and Congress duly amended the federal statute to incorporate the terms of the states' compromise. ${ }^{152}$ Nevada, South Carolina, and Washington, the three "sited states," would continue to accept radioactive waste for seven more years, until 1992. In the meantime, the "unsited states" would end their reliance on these sites, and this time, a series of incentives came with the bargain. ${ }^{153}$ The harshest of the incentives, a "so-called 'incentive," " in Justice O'Connor's words, ${ }^{154}$ offered the unsited states a choice: Provide for disposal of radioactive waste produced within your boundaries by 1996 or take title to it and become liable for all damages arising from possessing it. $^{155}$

149. Pub. L. No. $96-573,94$ Stat. 3347 (1980) (codified at 42 U.S.C. $\S \S 2021 b-2021 d$ (1988)).

150. The 1980 Act announced a federal policy of disposal "on a regional basis," and made each state "responsible for providing for the availability of capacity either within or outside the State for the disposal of low-level radioactive waste generated within its borders." $\$ 4(a)(1), 94$ Stat. at 3348 . The states were to enter regional compacts and were ultimately to receive congressional authorization to limit their sites to waste generated within the region. \& 4(a)(2)(B), 94 Stat. at 3348.

151. See New York, 112 S. Ct. at 2415.

152. Low-Level Radioactive Waste Policy Amendments Act of 1985, Pub. L. No. 99-240, 99 Stat. 1842 (codified at 42 U.S.C. $\$ \S 2021 b-2021 d$ ).

153. See New York, 112 S. Ct. at 2416 . Monetary and access incentives were included in the act along with the harsher incentive discussed in the text. The monetary incentives provided for a surcharge on out-of-state waste, a portion of which the Secretary of Energy would place in an escrow account for distribution to states that made progress toward developing new disposal sites. The access incentives allowed the sited states to gradually increase the cost of access and ultimately to deny access to their sites. According to the Court, these incentives were constitutional. Id. at 2427.

154. Id. at 2427.

155. 42 U.S.C. $\$ 2021 \mathrm{e}(\mathrm{d})(2)(C)$ (1988). Any producer of low-level radioactive waste would be able to invoke the "take title" provision. If the state failed to take possession of the waste, the state would be liable to the producer of the waste for any damages "direct or indirect," resulting from the failure. Id. 
New York, a state with a large proportion of the country's radioactive waste, attempted to comply. It proposed five sites, but predictably, the nearby residents objected. ${ }^{156}$ New York had opportunely taken advantage of the extended access to the out-ofstate disposal sites. But now, facing a choice between voter wrath and the unthinkable option of taking possession of immense amounts of radioactive waste, New York sued, presenting Tenth Amendment and federalism arguments. ${ }^{157}$

\section{Justice O'Connor's Democratic Theory of Normative Feder-} alism. In New York, Justice O'Connor frankly called the Tenth Amendment a "truism" 158 and a "tautology."159 It is one of many places in the Constitution where the "federal structure of our Government"160 is described.

In the end, just as a cup may be half empty or half full, it makes no difference whether one views the question at issue in this case as one of ascertaining the limits of the power delegated to the Federal Government under the affirmative provisions of the Con-

156. New York, 112 S. Ct. at 2416-17.

157. See id. at 2417. The two counties in which the proposed sites were to have been constructed also joined the suit. Id. The state cited the Tenth and Eleventh Amendments, with the Due Process Clause of the Fifth Amendment, and the Guarantee Clause of Article IV. The state lost in the lower courts. 757 F. Supp. 10 (N.D.N.Y. 1990), affd, 942 F.2d 114 (2d Cir. 1991). By the time it reached the Supreme Court, it was asserting only the Tenth Amendment and the Guarantee Clause claims. The Court, in invalidating the "take title" provision, relied only on the Tenth Amendment and the structure of the entire Constitution, and avoided using the Guarantee Clause. 112 S. Ct. at 2432.

158. 112 S. Ct. at 2418 (quoting United States v. Darby, 312 U.S. 100, 124 (1941) ("a truism that all is retained which has not been surrendered")).

159. Id. The Court borrows Justice Story's explanation of the Tenth Amendment: "This amendment is a mere affirmation of what, upon any just reasoning, is a necessary rule of interpreting the constitution. Being an instrument of limited and enumerated powers, it follows irresistibly, that what is not conferred, is withheld, and belongs to the state authorities." Id. (citing 3 JOSEPH STORY, COMMENTARIES ON THE CONSTTTUTION OF THE UNITED STATES 752 (1833)).

160. Id. at 2429. Calling the two aspects of the Constitution "mirror images," the Court wrote: "If a power is delegated to Congress in the Constitution, the Tenth Amendment expressly disclaims any reservation of that power to the States; if a power is an attribute of state sovereignty reserved by the Tenth Ainendment, it is necessarily a power the Constitution has not conferred on Congress." Id. at 2417 (citing United States v. Oregon, 366 U.S. 643, 649 (1961); Case v. Bowles, 327 U.S. 92, 102 (1946); Oklahouna ex rel. Phillips v. Guy F. Atkinson Co., 313 U.S. 508, 534 (1941)). 
stitution or as one of discerning the core of sovereignty retained by the States under the Tenth Amendment. ${ }^{161}$

In Garcia v. San Antonio Metropolitan Transit Authority, ${ }^{162}$ Justice Blackmun's majority opinion turned away from the Tenth Amendment and rejected the role of the courts in enforcing any sort of affirmative state sovereignty. But Garcia dealt with Congress's power to bind the states to a federal statute, not with the issue of whether Congress could force the states to enact legislation themselves. Caselaw not addressed by Garcia had established that Congress cannot "cominandeer[] the legislative processes of the States." 163 So Congress could not simply command the states to design plans for the disposal of radioactive waste. Offering the states a choice might have seemed to promise a way around this caselaw. But when Justice O'Connor discussed alternatives of regulating or taking title, she put the word "choice" in quotation marks: Congress cannot simply force the states to take

161. Id. at 2419 .

162. 469 U.S. 528 (1985); see supra text accompanying notes 89-107.

163. Hodel v. Virginia Surface Mining \& Reclamation Assn., 452 U.S. 264, 288 (1981). Yet O'Connor's own attempts to extend the principle of Hodel have proved unsuccessful. In FERC v. Mississippi, 456 U.S. 742 (1982), the majority accepted a federal energy statute that preempted state law, required state regulatory agencies to consider whether to adopt federal standards, and prescribed procedures governing the application of the federal standards. The majority-even during the reign of National League-viewed the imposition on the state as no more disturbing than the requirement that state courts apply federal law. Dissenting, Justice O'Connor viewed the arrangement with alarm as a "conscript[ion of] state utility commissions into the national bureaucratic army." Id. at $\mathbf{7 7 5}$ ( $O^{\prime}$ Connor, J., concurring in part and dissenting in part). O'Connor saw the comparison of state regulatory agencies to courts as "facile" because unlike courts, they normally choose what matters to address and this choice is "a fundamental attribute of legislative power." Id. at 785 . Federal interference with this power "unavoidably undermines state sovereignty." Id. FERC reveals the same concern with political accountability that characterizes O'Connor's majority opmions in Gregory and New York. Compelling state agencies to act, "unlike pre-emption, blurs the lines of political accountability and leaves citizens feeling that their representatives are no longer responsive to local needs." FERC, 456 U.S. at 787 (O'Connor, concurring in part and dissenting in part) (citing Richard B. Stewart, Pyramids of Sacrifice? Problems of Federalism $\dot{m}$ Mandating State Implementation of National Environmental Policy, 86 YALE L.J. 1196, 1239-47 (1977); Comment, Redefining the National League of Cities State Sovereignty Doctrine, 129 U. PA. L. REv. 1460, 1477-78 (1981)). To O'Connor, the states represent immense potential for experimenting with new solutions to national problems, but "[c]itizens . . cannot learn the lessons of self-government if their local efforts are devoted to reviewing proposals formulated by a faraway national legislature." Id. at 790 (O'Connor, J., concurring in part and dissenting in part). Though Gregory imported much of O'Connor's FERC dissent, she did not consider overruling FERC. Instead, she distinguished the arrangement in Gregory as offering the states no real choice. 
title, and it cannot force the states to legislate, so Congress cannot avoid constitutional difficulty by giving the states a choice between these two unconstitutional alternatives. ${ }^{164}$

But why speak as if Congress had bullied and coerced the states? Congress rubber-stamped a bargain struck by state officials. New York voluntarily participated in the bargaining process and took the benefit of continuing to use disposal sites in other states. It is at this point that Justice O'Connor cited Justice Blackmun's conception of federalism as having the purpose of "secur[ing] to citizens the liberties that derive from the diffusion of sovereign power." 165 In Justice O'Connor's words:

The Constitution does not protect the sovereignty of States for the benefit of the States or state governments as abstract political entities, or even for the benefit of the public officials governing the States. To the contrary, the Constitution divides authority between federal and state governments for the protection of individuals. ${ }^{166}$.

Thus, state officials cannot authorize Congress to exceed its constitutional powers, because the ultimate beneficiaries of the safeguards of federalism are the citizens of the states.

Justice O'Connor painted federalism as part of the structure of a functioning democracy. To permit state officials to reach an agreement that Congress then enacts into federal law is to exclude the beneficiaries of federalism from the process. If Congress merely encourages state regulation, state governments remain responsive to the local electorate's preferences; state officials remain accountable to the people. But when Congress compels the states to regulate, "the accountability of both state and federal officials is diminished."167 If people cannot locate the source of their distress when, say, a radioactive waste site is planned for their neighborhood, they will not know whom to vote out of office. Coopera-

164. New York, 112 S. Ct. at 2420.

165. Id. at 2431 (quoting Coleman v. Thounpson, 111 s. Ct. 2546, 2570 (1991) (Blackmun, J., dissenting)).

166. Id. at 2431 (citing Gregory v. Ashcroft, 111 S. Ct. 2395, 2400 (1991) ("Just as the separation and independence of the coordinate Branches of the Federal Government serves [sic] to prevent the accumulation of excessive power in any one Branch, a healthy balance of power between the States and the Federal Government will reduce the risk of tyranny and abuse from either front."); THE FEDERALIST No. 51, supra note 2, at 323 (James Madison)).

167. Id. at 2424 . 
tive federalism can become a tempting device for insulating officeholders at both the state and federal levels.

One could see this insulation as acceptable, even salutary, at least when it is used to structure solutions to overwhelming problems that have no popular solution. Justice White, dissenting from the invalidation of the "take title" provision, had little patience with the democracy argument:

Ultimately, I suppose, the entire structure of our federal constitutional government can be traced to an interest in establishing checks and balances to prevent the exercise of tyranny against individuals. But these fears seem extremely far distant to me in a situation such as this .... . For me, the Court's civics lecture has a decidedly hollow ring at a time when action, rather than rhetoric, is needed to solve a national problem. ${ }^{168}$

The majority, refusing to bow to expediency in the face of a serious-enough problem, elevated federalism to the level of separation of powers. To argue that consent could not overcome constitutional structure, Justice O'Connor cited instances in which the Court refused to accept congressional inroads into presidential power despite the president's consent. ${ }^{169}$ In Justice O'Connor's analysis, the same adherence to fundamental structure, unaffected by consent or expediency, that prevails in separation of powers analysis applies to federalism analysis, because federalism, like separation of powers, is a device for protecting the interests of the state's citizens, and not a possession of the state's officeholders. Those agents of the state therefore cannot waive the protection of federalism to serve their own interests.

New York involved a blurring of the source of unpopular law comparable to a state court's blending of state and federal law in Michigan v. Long. ${ }^{170}$ This time, state and federal officials perhaps had hoped to achieve their desired goals and to insulate themselves from voter wrath by making responsibility difficult to trace. Everyone could find someone else to blame. Cooperation yielded insulation. This was a federalism good for officeholders, but bad

168. Id. at 2444 (White, J., dissenting) (footnote omitted).

169. Id. at 2431 (citing Buckley v. Valeo, 424 U.S. 1, 118-37 (1976) (voiding Congress's infringement of president's appointment power, even though the president had signed the law); INS v. Chadha, 462 U.S. 919, 944-59 (1983) (invalidating legislative veto because it violates Presentment Clause, despite the president's signature)).

170. 463 U.S. 1032 (1983); see supra text accompanying note 43. 
for democracy. State officials, such as the governors who proposed the radioactive waste legislation, and members of Congress could find personal benefits within the intermingled structures of cooperative federalism. The Court would not permit them to efface the lines of accountability, even to get an important job done. They must legislate "in full view of the public" and "suffer the consequences if the decision turns out to be detrimental or unpopular."171

\section{CONCLUSION}

This Article has described and expanded upon two competing conceptions of the meaning of federalism, demonstrating how they edge close to convergence at one level of abstraction and veer far apart in particular cases. They converge on the level of "normativity": Both Justice Blackmun and Justice O'Connor assume the need for present-day purpose and value for federalism. Neither Justice accepts "blind deference" to the states, a respect ascribed to the states' mere existence or their historical status at the time of the founding of the Constitution. Indeed, both Justices reject the notion that the states are the beneficiaries of federalism. Federalism remains a force in their analysis because it functions for the benefit of human beings, the citizens of states. Neither Justice considers the option of simply banishing federalism from the analysis; both Justices have striven to imbue federalism with meaning that people today can find satisfying.

Blackmun and O'Connor (and the various Justices who have lined up behind them in the recent caselaw) diverge sharply about this meaning. Blackmun, in the tradition established by Justice Brennan, has made federalism instrumental to the furtherance of the rights of individual citizens. One may very well criticize this federalism as no federalism at all: Blackmun, like Brennan before him, has essentially inserted the word federalism in what could otherwise be an argument premising federal jurisdiction on the need to enforce federal rights. He does not seriously consider deferring to state courts for the purpose of enforcing federal rights, even though state courts under the Supremacy Clause have the obligation to follow federal law and may in some instances serve as fully competent-and particularly expeditious-fora for

171. New York, 112 S. Ct at 2424. 
this purpose. Moreover, once one moves beyond federal jurisdictional doctrine, Justice Blackmun's theory of federalism seems to lose any applicability. In the substantive federalism cases, the supremacy of federal law wins out over any assertion that the states deserve special treatment. Seeing the importance of national supremacy to Blackmun in these cases, the honest reader is perhaps compelled to admit that the federal jurisdictional cases do no more than express this fundamental belief in the importance of national supremacy. In what way does federalism further the rights of individuals? Blackmun's theory seems to lack any substance except as a basis for rejecting attempts by the states and their courts to claim entitlement to deference and as a rhetorical device capable of capturing the opposition's most powerful word.

We may equally well unveil O'Connor's theory of federalism. Prodded by Blackmun's harsh criticism in Coleman, which accused her of embracing a federalism that had no normative value, O'Connor took up the challenge. She made a rhetorical move seemingly designed to borrow some of the other side's moral power: She proclaimed her commitment to the well-being of the people. Her federalism came not as a case-by-case judicial vindication of mdividual rights-individual rights received little or no regard in her federalism scheme. Instead she looked to the democratic process and to strengthening the responsiveness of state government to the electorate. Through legal doctrine, Justice O'Connor has devised mechanisms for exposing government officials to the judgment of the electorate. But when democracy is not at stake, as when constitutional rights against the state are claimed, O'Connor's theory falls out of the picture. Her habeas corpus opinions seem to reflect the kind of empty deference to the states that she disowns in the substantive federalism cases. Thus one may rightly ask whether O'Connor's democratic theory of federalism too lacks substance and works only as a rhetorical flourish in substantive federalism cases.

It may be that, in context, the two normative federalisms have nothing in common: Justice Blackmun and Justice O'Connor will merely take turns asserting possession of the word "federalism," and will have nothing really to say to each other. Blackmun's theory will continue to support assertions of federal power, both by Congress and the federal courts, and O'Connor's theory will continue to support concessions to the states that cut against assertions of federal power. Nevertheless, after observing a Court so 
marred by deep division and rancor in recent years, one searches for signs of emerging harmony. After the many dismissive opinions the Justices have aimed at each other, including Blackmun's attack on O'Connor in Coleman, O'Connor's opinion in New York $v$. United States seems to open a period of negotiation. As unsatisfying and incoinplete the theories of federalism described in this Article may strike the reader, the beginning of a dialogue under the rubric of "federalism" may look promising. Justice O'Connor has received wide notice as the leader of the Court's new, moderate center; and she deserves further credit for leadership in resisting the temptation to return bitter words for bitter words and for making this bid to restore intelligent-perhaps even open-minded-dialogne to the Court.

But where can this dialogue go? Is it doomed upon descent from the level of high abstraction? I would suggest that the two opposed sides may find common ground by analyzing the relative capacities of the different governmental institutions involved in federalism issues. It may be possible to give substantial value to individual rights and to the democratic process by looking realistically at the contribution to be inade by the state courts. If the Blackmun theory of federalism, which places individual rights at its center, were to loosen its fixation on the idea that rights are impaired unless they receive enforcement in federal court, that theory could include a reevaluation of the role of the state courts. If federal jurisdictional doctrine forms an incentive structure designed to insulate only those state courts that provide a genuinely competent and unstinting review of all claims of federal right, then some deference to the states is normative in a way that could be compatible with Blackmun's basic values. State courts could earn deference in the form of, say, freedom froin habeas review, if their work rose to a sufficiently high standard, which the federal courts would apply seriously and without undue delicacy and "comity." The O'Connor theory is also compatible with this position. Her acceptance of the states' interest in "finality" or the state judges' "dignitary interest" in being left alone in habeas cases should not suffice. Serious scrutiny of the state courts' work ought to precede deference. If Justice O'Connor were to reconceive the states' independent functioning as a tool for enhancing the enforcement of rights, she might develop her theory of normative federalism to the point where it would command respect both on and off the Court. 